\title{
(SOBRE)VIVENDO EM MEIO AO CAOS: O POTENCIAL DA LITERATURA E DO AFETO NA EDUCAÇÃO LINGUIISTICA CRÍTICA
}

\author{
LIVING AMID AND THROUGH CHAOS: THE POTENTIAL OF LITERATURE AND AFFECT \\ IN CRITICAL LANGUAGE EDUCATION
}

\author{
Guilherme Jotto Kawachi*
}

\begin{abstract}
RESUMO
Os efeitos devastadores da pandemia de coronavírus têm impactado muitas esferas da sociedade, impondo contextos de (sobre) vivência marcados pela banalização da vida. Em um cenário em que a esperança parece ser invisibilizada, torna-se premente a construção da crítica (GARCIA, 2019) na educação (linguística), que, nessa perspectiva, é um espaço de resistência. Nesse contexto, o objetivo deste artigo é debater as produções discentes resultantes de um projeto didático desenvolvido no segundo semestre de 2020 em uma disciplina de língua inglesa oferecida para alunos de graduação na Universidade Estadual de Campinas. O projeto parte de um conto de Margaret Atwood para suscitar reflexões sobre a estrutura narrativa e as temáticas postas em circulação, como feminismo e relações interpessoais. O trabalho se amparou na noção de letramentos literários (COSSON, 2020) como prática social, isto é, na literatura como um espaço de materialização discursiva de problemas, sensibilidades e histórias postas no mundo, almejando, assim, criar espaços de afeto (ROCHA, 2020) e sentimento (hooks, 2017) apesar dos distanciamentos vivenciados. A pedagogia dos multiletramentos (COPE; KALANTZIS, 2000) embasou a natureza teóricometodológica das atividades, e as produções discentes são analisadas a partir de uma visão discursiva de língua/linguagem, também sob a ótica do letramento crítico (LUKE, 2014; MILLS, 2016; MONTE MOR, 2018). Sem intenção de romantizar um período tão doloroso, a expectativa é que as reflexões aqui compartilhadas possam inspirar os leitores a visibilizar esperança (no sentido freireano) que parece opaca em tempos sombrios.

Palavras-chave: educação linguística; língua inglesa; letramento literário; letramentos críticos; afeto.
\end{abstract}

\section{ABSTRACT}

The devastating effects of the coronavirus pandemic have impacted various spheres of social life, forcing us all into survival situations marked by the trivialization of life and, consequently, a loss of hope. In this scenario, language education is seen as space of resistance in which criticality is an urgent need. In light of these events, the objective of this article is to discuss students' work resulting from a project carried out during the second semester of 2020 in an undergraduate English as an Additional Language course at the State University of Campinas, Brazil. The project takes on a short story by Margaret Atwood to raise debates both on the narrative structure of the tale and its central themes, such as feminism and interpersonal relationships. The concept of literary literacy (COSSON, 2020) guided the development of the project, in which literature is conceived as a place where problems, sensitivities, and stories can be discursively materialized, leading to the emergence of spaces of affect (ROCHA, 2020) and feeling (hooks, 2017), despite the distancing experienced on so many levels. The methodological/ theoretical foundations of the activities were based on the multiliteracies pedagogy (COPE; KALANTZIS, 2000); students' works were analyzed from a discursive viewpoint of language and in light of critical literacy theories (LUKE, 2014; MILLS, 2016; MONTE MOR, 2018). Far from trying to romanticize such painful times, the reflections raised here aim to restore hope (in freirean terms) which seems opaque in times of crises.

Keywords: language education; English language; literary literacy; critical literacy; affect.

\section{ALGUMAS PALAVRAS SOBRE A DESUMANIZAÇÃO NO "NOVO NORMAL": NORMAL PARA QUEM?}

É difícil narrar o cotidiano assombroso que se materializa em frente aos nossos olhos dia após dia: pessoas impossibilitadas de se aproximarem fisicamente; rostos, sorrisos e expressões cobertas para garantir a segurança e a chance à vida; afetos, emoções, medo e sentimentos que se confundem e, por vezes, se tornam inexprimíveis diante da profusão de privações que parecem não cessar. Estamos, ainda, forçadamente reconfigurando e renegociando com instâncias políticas, espirituais, e de tantas outras ordens capazes de nos fortalecer - nossa (sobre)vivência em meio ao caos.

Poderia usar, sob um ponto de vista mercadológico e cruel, a palavra prejuízos para aludir aos efeitos das crises associadas à pandemia de coronavírus que assolou o mundo em 2020 e que serão sentidos por muitos anos. É claro, todavia, que como educador intensamente inspirado por uma pedagogia da esperança (FREIRE, 2014) e do amor (hooks, 2017), digo que são as perdas, nos sentidos amplamente dolorosos da palavra, que nos perseguirão. Em uma

\footnotetext{
* Universidade Estadual de Campinas (Unicamp), Campinas, SP, Brasil. jotto@unicamp.br Orcid: https://orcid.org/0000-0001-8625-2660
} 
conjuntura social e política em que testemunhamos, todos, a naturalização da morte orquestrada pelos instrumentos sombrios de uma necropolítica (MBEMBE, 2016), nós, professores, ainda encontramos forças para marcar nossa existência (e resistência) através da educação. Por quê?

Busco, neste texto, explicitar minhas compreensões acerca dos porquês, das forças que nos impulsionam a seguir apesar do contexto de ataque à ciência, de demonização do dissenso, de cerceamento da voz dos professores, de desconsideração da vida, enfim, de todo o peso que, por vezes, parece ser insustentável. Antes de tudo, entendo, com Liberali (2020, p. 15), que resistimos em tempos sombrios porque o papel da educação é, em primeiro lugar, "buscar a vida para, então, buscar o ensino-aprendizagem".

A força do vírus e os seus efeitos vinculados à necropolítica reverberam em nossas ações dentro ou fora da escola. Em qualquer que seja o espaço, o vírus remove nossa liberdade e nos impede de exercermos nossa humanidade ao nos afastar, como bem pontua Rocha $(2020$, p. 115), do que "nos torna pessoas, seres políticos - a vida social e coletiva" (ênfase adicionada).

No âmbito escolar, alguns de nós (me incluo aí) desfrutam do privilégio paradoxal de podermos, em casa, ressignificarmos nossas identidades docentes e propostas didático-pedagógicas em um ensino remoto/emergencial que, conforme sugerem Liberali e colaboradores (2020), certamente carece de mais investigações. Em que pesem as contribuições bem-intencionadas de instituições e de pessoas em geral em viabilizar o ensino a partir de recursos tecnológicos (alguns dos quais desenvolvidos em caráter de urgência), não há nada pessoal e humanizador na impossibilidade de compartilhar experiências com nossos alunos, de vê-los, de ouvi-los e até mesmo de tê-los conosco em uma aula, para citar apenas algumas dificuldades. Urgente, então, é resgatar a sala de aula como um lugar de intimidade, sentimento e prazer, já dizia hooks (2017).

A instauração sistemática de recursos tecnológicos em espaços educativos não é recente, mas a experiência inevitável do ensino remoto em face de todas as restrições já conhecidas escancarou, como alertava Selwyn (2017, p. 138) muito antes do contexto pandêmico, "o papel da tecnologia digital na perpetuação de vantagens acumuladas e da reprodução das desigualdades". Nos meandros de um sistema capitalista que nutre e é nutrido por profundas discrepâncias sociais em favor de uma elite branca, masculina e heteronormativa, o estudante menos favorecido segue em desvantagem, não raro sem condições de dar andamento aos estudos seja por falta de suporte financeiro e psicológico para realizar as atividades didáticas, seja pelas "novas" configurações de ensino e trabalho e suas estruturas complexas.

Nessa conjuntura, como sabiamente sintetizam Nóvoa e Alvim (2020), tem-se a sensação de que "não há nada novo, mas tudo mudou": apesar de estarmos vivendo momentos de horror possivelmente nunca antes vividos, as desigualdades seguem perpetuadas, o "sujeito do desempenho" segue explorando (e culpando) a si próprio às custas da ilusão meritocrática do sucesso à la do it yourself, que parece ser a lógica da sociedade do cansaço e do esgotamento (HAN, 2017).

Nas bases do projeto de desumanização da sociedade ultra/neoconservadora estão os discursos de fechamento, de negação ao diferente, de exclusão, de ódio, que, conforme ilustram Duboc e Ferraz (2018), se materializam nos muros erguidos para separar nações, nas paredes pintadas de cinza para apagar as cores da diversidade, entre muitas outras formas violentas de separação. Cabe frisar, contudo, que não estou defendendo uma posição ingênua e politicamente perigosa em favor de uma unidade/união celebratória, já que, como discutem Cervenak e colaboradores (2002), o discurso da união favorece a eliminação violenta da diferença. Trata-se, então, de sustentarmos uma "política de escuta" amparada na prática de ouvir com empatia e respeito para além do discurso conservador da união.

Entre muros erguidos, cores apagadas e vidas banalizadas, perdemos, como resume Rocha (2020, p. 119) "a humanitas, o processo de transformação dos seres biológicos em seres políticos, públicos, cidadãos da pólis. Em outras palavras, nos desumanizamos".

Parecemos estar, assim, encurralados por ameaças constantes: de um lado, a força devastadora do vírus; de outro (ou do mesmo?), o poder igualmente fatal da necropolítica; ambos nos impõem a difícil vivência da privação de nossa humanidade. No contexto educativo, essa conjuntura evidencia, então, a necessidade premente de defendermos "a ideia de que a escola e a pedagogia são, sobretudo, espaços comuns - e nada disso se faz em casa" (NÓVOA, 2021, s/p).

Alinho-me, portanto, a Nóvoa (2021) na certeza de que a escola e outras instituições educacionais não poderão sobreviver ilesas dos impactos da crise para nossas "certezas" epistemológicas, teóricas, metodológicas e de muitas outras naturezas. É urgente que possamos viabilizar, colaborativamente e estrategicamente, momentos e espaços de desaprendizagem para promover uma reaprendizagem (unlearn to relearn), como aponta García (2020b). Para a 
educação linguística, especificamente, questionar o que fazemos com língua e quais sentidos damos vazão com as práticas de linguagem que propomos torna-se ainda mais necessário, já que "a educação linguística tem servido como uma forma de apoio a processos de minoritarização, racialização e persistência da colonialidade" (GARCIA, 2020a, p. XIX).

Em outro âmbito dessa discussão, em situação certamente mais vulnerável, estão professores que são levados a darem suas aulas presencialmente, muito antes de qualquer perspectiva de proteção vacinal, sob o discurso neoliberal nefasto segundo o qual "não podemos parar", afinal, no "novo normal", as coisas são, mesmo, assim.

Para além dos questionamentos de como ocorrerá o retorno às aulas presenciais, ou de que maneira a economia sobreviverá à crise que se instalou, talvez a questão mais urgente e carente de reflexões seria: em que mundo - e para quem - tudo isso é "normal"? Ou, de modo mais direto, como o fazem Menezes de Souza e Monte Mor (2021, p. 663): "isso é normal?"

Esses autores argumentam que a sustentação desses discursos favorece os interesses da lógica neoliberal na qual "mercado e economia são primordiais, e nós, como cidadãos, precisamos continuar trabalhando para continuar movendo a economia" (MENEZES DE SOUZA; MONTE MOR, 2021, p. 663). Seguimos, assim, ainda mais nos isolando, nos individualizando, e buscando (sobre)viver em um cansaço solitário (HAN, 2017) que mina nossa capacidade de empatia e, como tenho argumentado, nossa humanidade.

Em um cenário de tantos fardos a serem suportados, retomo minha busca individual e coletiva por compreensões para tantos porquês. Por que seguimos em frente e que sentidos criamos em nossas salas de aula em tempos tão carentes de sentimento e afeto? Entendo, com Nóvoa (2021), que isso se deve ao fato de que nós, educadores, somos "impenitentes otimistas" e, mesmo diante de muitas situações-limite, seguimos em busca do inédito-viável (FREIRE, 2014; LIBERALI, 2020). Assim, esperançamos teimosamente (no sentido freireano), porque esperançar é parte de nossa existência e mostra-se, portanto, uma necessidade ontológica (FREIRE, 2014). Não há como ser diferente.

Como creio ter ficado evidente, acredito, ao lado de outros colegas e autores, em uma educação (linguística) de bases éticas e críticas que valorize e favoreça tanto o saber quanto o sentir (NOVOA, 2021), ou seja, uma prática educativa capaz de resgatar o entusiasmo (hooks, 2017) de viver a pedagogia e, assim, de potencializar a produção de conhecimento acatando o dissenso inerente à vida humana (DUBOC; FERRAZ, 2018). Colocado de outra forma, me amparo em uma educação linguística que antes de oportunizar o ensino de língua possa se constituir em um espaço amplo de empatia, afeto e sentimentos.

Em tempos de afetos tristes (ROCHA, 2020) como o ódio, a frustração, a angústia, entre tantos outros, encontrei amparo na minha paixão antiga por literatura ao buscar compreender os porquês que me/nos cercam a todo momento. Reprojeto, então, para a minha prática docente, o potencial acolhedor da literatura, compreendida, aqui, como uma potência de emoções, sentimentos, deslocamentos e rupturas que atravessa minhas identidades e se refaz, em momentos de crise, em força ao mesmo tempo acalentadora e desestabilizadora, portanto, caleidoscópica como sou e como somos todos/todas nós. Assim, revozeio Antonio Candido (2004, p. 186), que diz melhor:

A literatura corresponde a uma necessidade universal que deve ser satisfeita sob a pena de mutilar a personalidade, porque pelo fato de dar forma aos sentimentos e à visão do mundo ela nos organiza, nos liberta do caos e, portanto, nos humaniza. Negar a fruição da literatura é mutilar a nossa humanidade.

É a partir dessa ótica que discuto, neste artigo, as produções discentes resultantes de um trabalho com um texto literário em uma disciplina regular de Língua Inglesa, oferecida para alunos de graduação da Universidade Estadual de Campinas (Unicamp) no segundo semestre de 2020. Na ocasião, a literatura se mostrou um caminho muito potente para destotalizar as experiências desumanas que permeavam nossos cotidianos e para estabelecer relações de afeto, fomentando, também, o trabalho com letramento crítico, conforme explico mais adiante. Antes disso, coloco em debate alguns pressupostos teóricos que têm atravessado minhas práticas docentes e que nortearam a elaboração do projeto didático que deu origem às produções discentes mencionadas.

\section{A LITERATURA NA CRITICIDADE E NA AFETIVIDADE DOS LETRAMENTOS}

Como tenho argumentado, a distopia do novo normal (MENEZES DE SOUZA; MONTE MOR, 2021) e a (sobre)vivência no ensino remoto instauraram um contexto de muitas privações no qual nós - alunos e professores fomos "forçados" a interagir, seguindo o discurso neoliberal que rege o sujeito do desempenho (HAN, 2017). Para 
além das problematizações já apontadas e das dúvidas que permeiam esses tempos, me pergunto: o que fazemos da educação linguística e como visibilizamos a esperança em meio a crises de ordens sanitária, ética, política e existencial?

Sem qualquer intenção de romantizar um período de tantas dores e perdas, concordo com Takaki (2019, p. 200) no argumento de que a crise "não é uma totalidade estática", e nossa (sobre)vivência nesse cenário "faz brotar a vontade de fazer algo". É evidente que, junto à autora, não falo de "algo" a esmo, mas de práticas pedagógicas politicamente engajadas, socialmente relevantes, que, amparadas em uma visão discursiva e situada de língua/ linguagem, acatam as incertezas como parte necessária para a viabilização de transformações em uma educação transgressora e libertária (hooks, 2017), com vistas a um mundo menos desumano e, portanto, mais justo para todos.

Assim, em que pesem todos os fardos que estamos carregando em nossas práticas educativas, faz-se necessário pontuar, como o faz Nóvoa (2021), que existe aprendizagem durante a pandemia (e porque somos impenitentes otimistas, cabe a repetição, sempre existirá). Insisto, então, na força da educação linguística em resistir à necropolítica e, mesmo em situação de luto, em fomentar a criatividade sempre enunciada a partir de um lugar de crítica (GARCÍA, 2020a). Com isso, ao revisitar minha prática e ao observar a de meus colegas, não há dúvidas de que para além do ensino de aspectos linguístico-discursivos - que, vale a ressalva, é um objetivo legítimo e por isso integra as ementas de nossas disciplinas de línguas na universidade e nossos currículos na escola - há muitas propostas sendo desenvolvidas a partir de esforços coletivos com foco em leituras diversas, levando a produções que suscitam debates sobre a natureza multissemiótica da linguagem, entre tantas outras experiências enriquecedoras que partem do desejo e da necessidade da escola de, reitero, resistir e esperançar.

O ponto, aqui, como assevera Nóvoa (2021), não é sugerir a substituição da aprendizagem curricular, mas fomentar uma nova relação com os conhecimentos e a pedagogia apesar de todos os pesares e, dessa forma, sinalizar que existe aprendizagem para além daquela tradicionalmente curricularizada.

A esse respeito, é importante pontuar que os desdobramentos de novas configurações sociais para a educação linguística já eram discutidos desde 1996 pelos pesquisadores do Grupo de Nova Londres, à frente da pedagogia dos multiletramentos (COPE; KALANTZIS, 2000), cujas premissas teóricas e epistemológicas se voltavam para a compreensão das práticas de linguagem em novos contextos de diversidade linguística, cultural e midiática. O trabalho seminal desses pesquisadores proporcionou debates significativos para o entendimento (da concepção e do uso) da linguagem em diferentes esferas da vida social, trazendo, também, contribuições importantes para a educação linguística voltada para a cidadania. Nessa direção,

os multiletramentos criam uma diferente forma de pedagogia: uma em que a língua e outros modos de sentido são recursos representacionais dinâmicos que estão constantemente sendo refeitos por seus usuários conforme eles trabalham para alcançar propósitos culturais variados (COPE; KALANTZIS, 2000, p. 5)

Importa, aqui, salientar a visão de língua sociohistoricamente situada, performativa e não-estanque que está no cerne dessas teorizações e que se expandiram para os estudos de novos letramentos, letramentos múltiplos e multissemióticos (ROJO, 2009), porque essa concepção contribui para ampliarmos uma visão de língua para além das padronizações e normatizações que são sempre excludentes, sobretudo para grupos minoritarizados. Desse modo, essas teorizações evidenciam, tal qual discute García (2019), que os sistemas multissemióticos não são suportes para práticas de linguagem: eles são a linguagem.

Segundo García (2019, p. 13), em uma visão translíngue, a língua é sempre um movimento, um verbo, o que destaca a necessidade de ampliarmos nossas visões para além das línguas nomeadas, já que, nessa perspectiva, nossos alunos podem explorar o potencial de seus conhecimentos e repertórios semióticos - dos quais a língua é uma parte importante, mas não a única - para construir sentidos a partir da "arte, história, matemática, música, ciência, tecnologia, libertando suas paixões e criatividades, sem, antes disso, terem que provar que sabem usar aspectos padronizadores de língua".

Uma das contribuições mais importantes dos estudos dos novos/multiletramentos e, mais recentemente, da pedagogia translíngue para a educação linguística, a meu ver, é a sinalização da necessidade de aproximarmos os conteúdos focalizados na escola das práticas que já integram o universo do alunado (MONTE MOR, 2013). O objetivo, com isso, é fortalecer a relevância de currículos centrados em uma concepção de estudante que, longe de ser passivo no processo de aprendizagem, é, ao mesmo tempo, autor, leitor, comentarista, editor, entre muitas outras funções que ele/ela já assume no uso que faz da linguagem cotidianamente. É por isso que, nessa perspectiva, os 
novos letramentos e os repertórios multissemióticos dos estudantes devem ser entendidos como objetos de estudo e de prática na educação linguística.

Em sua premissa de ampliar compreensões sobre língua e pedagogia a partir de um novo/outro contexto sociohistórico, os multiletramentos também assumem um viés crítico porque buscam "criar condições para uma compreensão crítica dos discursos e do poder (...) a partir das quais condições de trabalho mais novas, mais produtivas e genuinamente mais igualitárias podem emergir" (COPE; KALANTZIS, 2013, p. 111).

Para além do foco na dimensão do trabalho, o viés crítico dos letramentos é fundamental para a efetivação de um trabalho situado, engajado e transformador com linguagem, e, nesse sentido, não se configura como uma fase a ser acoplada a um momento específico do processo educativo, mas atravessa todos os pontos do trabalho com linguagem. Isso porque o letramento crítico (LUKE, 2014; MILLS, 2016; MONTE MOR, 2018) não emerge somente na materialidade das diversas formas textuais, mas se vivencia nos debates, nas reflexões e nas ações em torno da linguagem.

Portanto, com Mills (2016, p. 48), entendo o letramento crítico como "um processo de aprendizagem de letramentos que possibilita ao estudante se tornar consciente de sua posição histórica em relações de poder ideológicas em uma educação democratizadora". Assim sendo, viver o letramento crítico na educação linguística implica assumir uma posição incessantemente questionadora dos sentidos evidenciados em nossas práticas de linguagem diárias, seja na seleção das temáticas a serem abordadas, no desenvolvimento do material e das propostas práticas, no desenho das produções solicitadas e do sistema avaliativo. Todos esses momentos consistem em oportunidades estratégicas para a construção da crítica e para a expansão dos hábitos interpretativos de nossos alunos (MONTE MOR, 2018) sempre a partir de uma ótica que busca interrogar por quê as coisas são como são, buscando desvelar de que modo nossas práticas de linguagem cotidianas servem aos propósitos de perpetuar desigualdades.

Takaki (2021) nos lembra que o uso da língua para legitimar opressão também é um mecanismo poderoso em uma agenda neoliberal e extremista, sobretudo em direção aos grupos que representam a diferença. É nesse cenário que o letramento crítico se faz necessário, pois constitui resistência e luta. A própria natureza performativa da língua, nesse viés, permite às pessoas desafiarem, reconstruírem e questionarem uma dada realidade posta em um texto.

É preciso dizer, entretanto, que seguir o caminho do letramento crítico e da justiça social implica assumir o risco de ferir a macropolítica dos novos fascismos (LAZZARATO, 2019) e a micropolítica dos afetos tristes (como o ódio) (ROCHA, 2020). Não é surpreendente, assim, que nesses tempos tenebrosos, as premissas ultraconservadoras também dirijam à educação suas práticas violentas de silenciamento da diferença e da diversidade. Em junho/2021, um aluno do $6^{\circ}$ ano do Ensino Fundamental de uma escola pública de Campinas (SP) foi silenciado em um grupo de WhatsApp da escola ao sugerir que o tema do orgulho LGBTQIA + fosse trabalhado um projeto na instituição'; no mesmo mês e ano, em Vitória (ES), uma professora de inglês foi ameaçada por trabalhar com o significado da sigla LGBTQIA + em uma de suas propostas didáticas². A ocorrência dessas situações ratifica a premência de práticas voltadas para a criticidade e para a interculturalidade (KAWACHI, 2015), e muito longe de frear o trabalho com letramento crítico, elas reforçam que, mais do que nunca, processos de reflexividade e criticidade não são uma opção: são uma necessidade.

A esse respeito, endosso o que afirma Luke (2018, p. 6-7):

Havia um ataque concentrado no letramento crítico como uma forma nova de doutrinação politicamente correta. Ao longo do tempo, meu pensamento é que as abordagens críticas ao currículo são incorporadas nas disposições dos professores - isto é, uma vez que eles e seus alunos estão engajados em trabalhos críticos, questionadores, dialógicos e construtivistas acerca da formação do conhecimento, do texto e do discurso, da escrita e da imagem, do campo e da disciplina, não bá volta. (ênfase adicionada)

No ensino de línguas estrangeiras/adicionais, sobretudo no caso da língua inglesa, o potencial do letramento crítico mostra-se relevante diante de sua força desestabilizadora de vozes colonizadoras e hegemônicas vinculadas à figura do outro. Assim, o outro, eu, e nossos discursos podem ser continuamente ressignificados a partir de um processo investigativo que, centrado na reflexão crítica em torno das representações simbólicas evidenciadas na/ pela linguagem, pode contribuir para a compreensão dos interesses que motivam determinados sentidos em suas condições específicas de enunciação.

1. https:/g1.globo.com/sp/campinas-regiao/noticia/2021/06/13/familia-denuncia-preconceito-contra-aluno-de-11-anos-apos-sugestao-detrabalho-com-tema-lgbt-em-grupo-da-escola.ghtml

2. https://www.agazeta.com.br/es/politica/vereador-de-vitoria-diz-que-vai-acuar-professora-por-atividade-escolar-sobre-lgbt-0621. 
Além disso, nas perspectivas aqui sustentadas, o letramento crítico é chave para uma educação linguística que busque favorecer a empatia e o diálogo humanizadores. Trata-se, portanto, de uma experiência vivida no exercício constante de ler a nós mesmos enquanto lemos o outro (MENEZES DE SOUZA, 2011; DUBOC; FERRAZ, 2018). Assim sendo, faço minhas as palavras de Jordão (2019, p. 73/74), que defende o letramento crítico como uma forma de "ler o mundo e a si, observando-se implicado nos processos de construção de sentidos não apenas como um ser racional e consciente, mas também como alguém atravessado por emoções, afetos e desejos".

Exercendo, aqui, minha autoreflexividade crítica (TAKAKI, 2019) ao repensar minha atuação docente, vejo que o letramento crítico, desde muito tempo, fez-se presente em minhas práticas e nas interações com meus alunos, tanto como uma orientação formal para o trabalho com texto e discurso quanto como uma disposição incorporada, nos termos de Luke (2018). No ensino remoto, entretanto, mesmo com a tentativa de manter as propostas didáticas estabelecidas previamente, parecia circular, a todo momento, a sensação de descaracterização das minhas aulas como um espaço de entusiasmo, sentimento, intimidade (hooks, 2017) e amorosidade esperançada (FREIRE, 2014). "Tudo mudou" - mas o quê?

Recuperando reflexões anteriores, compreendo, agora, que além de todas as reconfigurações pelas quais passamos nesses tempos de horror, a separação física entre professor e alunos removeu, pelo menos para mim, em alguns momentos, o exercício cotidiano da afetividade na prática docente. Ainda que amparado pelas mesmas orientações teóricas e, em alguns casos, pelas mesmas propostas didáticas, o isolamento e a separação minaram a visibilização e a presença do afeto na sala de aula. Foi a partir do diálogo com os estudantes de uma disciplina que ministrei no início da migração para o ensino remoto, em 2020/1, que marcamos, juntos, a necessidade de redesenharmos algumas propostas daquela disciplina (o que se estendeu, posteriormente, para todas as outras oferecidas nesse contexto) a fim de que os espaços síncronos e assíncronos do curso pudessem, também, alimentar o encontro entre letramentos e afetividade. É nessa circunstância que a literatura emerge como forma artística e cultural capaz de mobilizar reflexões sobre língua e sobre questões diversas postas no mundo, como sigo discutindo.

Entendo, com Cosson (2020, p. 17), que "a literatura é uma experiência a ser realizada. É mais que um conhecimento a ser reelaborado, ela é a incorporação do outro em mim, sem renúncia da minha própria identidade". Fica evidente, então, que a literatura oportuniza um trabalho dialógico pautado no encontro e no confronto de discursos, identidades e visões de mundo minhas e do outro, e é nos entremeios da negociação de nossas diferenças que se abre espaço para a construção de sentidos e da crítica. E, recuperando Cândido (1995), é porque "a literatura nos humaniza" que através dela nos engajamos politicamente, socialmente e afetivamente.

Defendo, portanto, a literatura como força capaz de impulsionar o trabalho com letramentos críticos, multissemióticos (ROJO, 2009), visuais (FERRAZ; KAWACHI-FURLAN, 2019), entre tantos outros, mostrandose potencialmente transformadora em uma educação linguística comprometida com a formação cidadã (MONTE MOR, 2013) de seus estudantes. Nesse horizonte, ainda que a proposta de letramentos literários de Cosson (2020) tenha sido originalmente pensada para o ensino de língua materna, exalto seu potencial também para contextos de línguas adicionais. Seu objetivo, como explica Cosson (2020, p. 12), é:

formar uma comunidade de leitores que, como toda comunidade, saiba reconhecer os laços que unem seus membros no espaço e no tempo. Uma comunidade que se constrói na sala de aula, mas vai além da escola, pois fornece a cada aluno e ao conjunto deles uma maneira própria de ver e viver o mundo.

Sendo assim, foi no poder da literatura "de se metamorfosear em todas as formas discursivas" (COSSON, 2020, p. 12) que encontrei caminhos para ampliar o trabalho com letramentos críticos e, de maneira mais urgente, fomentar práticas afetivas em um ambiente pedagógico, por vezes, tão inóspito, como é o ensino remoto.

Todos os movimentos de mergulho em minhas próprias práticas, de mobilização de diálogos com os estudantes a fim de buscarmos estreitar nossas conexões em meio ao caos e de, em última instância, construirmos sentidos menos desumanos em tempos tão desumanizadores, evidenciam que não há como desconsiderar "a dimensão afetiva dos seres" e separá-la do exercício da cidadania nas práticas de letramento crítico, "a não ser que se que se negue o corpo, a voz, a performatividade, a relação" (JORDAO, 2019, p. 76).

Isso posto, apresento, na sequência, aspectos específicos sobre o contexto educacional em que atuo, e exponho, à luz das teorizações de multiletramentos (COPE; KALANTZIS, 2013) e dos letramentos literários (COSSON, 2020), a organização do projeto didático que deu origem às produções discentes focalizadas neste trabalho. 


\section{O CONTEXTO EDUCACIONAL E A PROPOSTA DIDÁTICA}

O Centro de Ensino de Línguas (CEL) da Unicamp, local em que atuo como docente de língua inglesa ${ }^{3}$, é responsável pelo oferecimento das disciplinas de língua adicional que, como cursos regulares de graduação, podem ser obrigatórias, eletivas ou extracurriculares, a depender dos diferentes catálogos e currículos. As disciplinas de língua inglesa têm como principal objetivo o desenvolvimento de habilidades linguístico-discursivas a partir do trabalho com textos multimodais em diferentes gêneros discursivos ${ }^{4}$. Assim como nas demais disciplinas de graduação da universidade, a ementa ${ }^{5}$ é o documento norteador dos princípios e práticas a serem desenvolvidos, mas os docentes exercem sua autonomia na condução das aulas, sobretudo na seleção dos materiais nos quais as propostas práticas estarão pautadas.

Certo de que a orientação para o letramento crítico é "um caminho sem volta", resgatando Luke (2018), essa teorização tem permeado minhas práticas docentes que, no contato com os alunos, se traduzem em oportunidades para vivenciar, interrogar e expandir os sentidos postos em textos diversos.

Os primeiros momentos da experiência com ensino remoto, no primeiro semestre de 2020, evidenciaram uma contradição: se, por um lado, não parecia coerente ignorar os aspectos sociais e políticos atrelados à conjuntura da pandemia, por outro, estávamos (e ainda estamos) extenuados diante da possibilidade constante das perdas, do medo, além de profundamente afetados pelo desamparo (político, emocional) que nos impedia de esperançarmos. Em diálogos com os alunos daquele período letivo, redesenhamos, juntos, algumas propostas práticas da disciplina, dando continuidade ao trabalho com criticidade e reflexividade a partir, também, de textos literários. Essas reformulações favoreceram movimentos de aproximação entre nós, mesmo diante da impossibilidade física da proximidade, além de oportunizarem a vivência da afetividade a partir da arte. Partimos da compreensão de que a leitura literária pode ser "exercida sem o abandono do prazer, mas com um compromisso de conhecimento que todo saber exige" (COSSON, 2020, p.23). O trabalho colaborativo com textos literários em língua inglesa, especialmente de autores que ecoam as lutas antirracista, antimachista, entre outras, também pode contribuir para a democratização de conhecimentos em uma educação menos desumana.

Naquele momento, o texto escolhido para a realização de algumas atividades na disciplina Inglês 2 foi "A Private Experience" (2009), da autora nigeriana Chimamanda Ngozi Adichie. Desde então, outros contos têm integrado as minhas disciplinas: "Sweetness" (2015), da estadunidense Toni Morrison, foi base para atividades da disciplina Inglês 2, em 2021/1; já o conto "Happy Endings" (1983), da canadense Margaret Atwood, foi focalizado na disciplina Inglês 1 , em 2020/2. Neste artigo, focalizo as produções discentes vinculadas ao trabalho com o texto de Atwood.

O conto foi escolhido, junto aos alunos, inicialmente a partir do nível de complexidade dos aspectos linguísticos do texto, compatíveis com os conteúdos estudados no curso Inglês 1. Além disso, as temáticas centrais do conto (feminismo, relações interpessoais e relacionamentos afetivos) também contribuíram para a sua escolha. Mesmo não sendo recente, o texto é inovador por ser estruturado em torno de 6 pequenas partes que, juntas, compõem uma metanarrativa. O enredo acompanha com dois personagens que seguem rumos distintos em cada uma das partes do texto, o que permite à autora questionar tanto a diversidade (e os desencontros) nas relações humanas quanto a própria estrutura tradicional de textos narrativos.

Em sua configuração fragmentada, a metanarrativa exige que o leitor transite ativamente pelas partes do texto a fim de se aproximar dos personagens e dos temas que ali circulam. Dessa forma, o conto reflete a própria natureza discursiva e não canônica da linguagem. Esses aspectos coadunam com uma visão translíngue (GARCÍA, 2020a; 2020b) de língua, linguagem e de pedagogia segundo a qual linguajar (languaging) é sempre um movimento.

O quadro a seguir apresenta informações específicas sobre o trabalho desenvolvido nesse contexto.

3. O CEL conta com docentes efetivos contratados via concurso público, enquadrados em uma carreira especial, e oferece disciplinas de alemão, espanhol, francês, hebraico, inglês, italiano, japonês, português para estrangeiros (PLE) e russo.

4. Na Unicamp, as disciplinas de inglês (assim como as demais oferecidas pelo CEL) não são voltadas para licenciandos em Letras; portanto, são abertas a todos os cursos de graduação. Isso significa que, tradicionalmente, os conteúdos dessas disciplinas assumem um caráter mais prático, voltando-se para os contextos de uso e produção de sentidos na/pela língua.

5. Disponível em https://www.dac.unicamp.br/sistemas/catalogos/grad/catalogo2021/disciplinas/la.html. 
Quadro 1. informações sobre o contexto de desenvolvimento do projeto

\begin{tabular}{|l|l|}
\hline Disciplina / carga horária semestral & Inglês $1 /$ 60h \\
\hline Alunos na turma & 22 \\
\hline Plataforma digital da disciplina & Moodle \\
\hline Material usado no projeto & Conto "Happy Endings", de Margaret Atwood \\
\hline Duração do projeto & 3 semanas (de 07 a 28/12/20) \\
\hline
\end{tabular}

Fonte: elaboração própria

Os alunos dessa disciplina eram, na época, graduandos em diferentes cursos da Unicamp: história, letras, ciência da computação, educação física, administração, química, economia, enfermagem e estatística. Isso ilustra que o CEL é sempre um espaço marcado pela diversidade, e as disciplinas de língua adicional são, então, um momento de encontro desses estudantes. Muitos, inclusive, sinalizam que as aulas do CEL representam um momento de quebra da rigidez acadêmica tão presente em seus programas de graduação.

A imagem a seguir ilustra a organização das atividades do projeto conforme foram apresentadas aos estudantes.

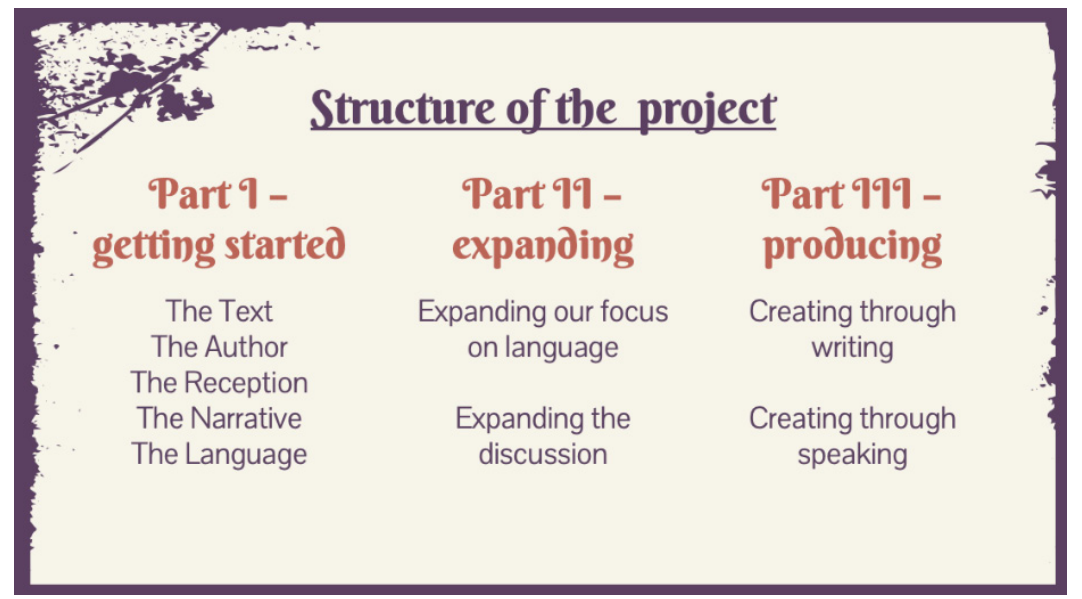

Imagem 1. organização do projeto

Fonte: elaboração própria

O desenho teórico-metodológico das atividades foi orientado pelas teorias de multiletramentos, especialmente nas dimensões "prática situada", "instrução explícita", "enquadramento crítico" e "prática transformada" propostas e revisitadas por Cope e Kalantzis $(2000 ; 2013)$. Vale frisar que essas dimensões não são entendidas de maneira segmentada; trata-se de movimentos didáticos que, à luz das teorias de língua e pedagogia que norteiam essa teorização, fomentam o trabalho com língua/linguagem a partir de diferentes enfoques.

De acordo com Cope e Kalantzis (2013), na prática situada o estudante vivencia o novo a partir daquilo que já conhece, em um momento de encontro dos seus conhecimentos e habilidades com os conteúdos da experiência didática em questão. A instrução explícita busca direcionar o olhar do estudante para os aspectos linguísticos em uma determinada proposta, buscando favorecer o trabalho com metalinguagem, conceituação e categorização que, certamente, podem contribuir para a compreensão de sentidos em textos diversos a partir de um olhar crítico. Nessa direção, é no momento de enquadramento crítico que se busca fomentar a análise funcional e crítica das relações de poder evidenciadas nos textos. Não há dúvidas de que, reforçando a fluidez entre essas dimensões, o enfoque crítico perpassa todos os momentos do trabalho com a linguagem. A prática transformada se volta para as produções discentes, constituindo, assim, um momento de materialização criativa dos conhecimentos em foco.

Esses momentos da pedagogia dos multiletramentos nortearam, portanto, a concepção das atividades do projeto e coadunam com a proposta de letramento literário de Cosson (2020). Para esse autor, a didatização da leitura literária na escola é um movimento legítimo a fim de democratizar o acesso à literatura de modo integrado ao trabalho com aspectos linguísticos. Nesse sentido, o autor propõe uma sequência básica para o letramento literário que inclui os momentos de motivação, introdução, leitura e interpretação. A exemplo das dimensões mencionadas dos multiletramentos, esses momentos não são, necessariamente, lineares, e por isso mesmo, contribuíram para a conceptualização do projeto como um todo e das atividades individuais que o integram. 
A divisão das atividades em três partes teve o propósito de contextualizar as temáticas e a linguagem do conto. É importante destacar, contudo, que a leitura integral do texto e a realização das atividades poderiam ser feitas a qualquer momento, não seguindo uma ordem linear. A primeira parte (getting started) buscava despertar a motivação do estudante por meio de propostas focalizadas, por exemplo, na vida e obra da autora, nas críticas recebidas pelo conto, nos elementos comuns em textos narrativos. Segundo Cosson (2020, p. 56), a contextualização (que pode ser teórica, histórica, temática, entre outras dimensões) representa um momento crucial no trabalho com letramento literário, pois "prepara o leitor para receber o texto, mas não silencia nem o texto nem o leitor". Ainda na parte I, a atividade "the language" buscava introduzir as principais características da linguagem do conto, podendo ser compreendida como uma aproximação entre prática situada, na visão dos multiletramentos, e a fase de introdução, dos letramentos literários.

A parte II expandiu o foco nos aspectos linguísticos e nas temáticas do texto a partir de excertos do conto, remetendo aos momentos de leitura e interpretação da proposta de Cosson (2020) e às dimensões instrução explícita e enquadramento crítico dos multiletramentos.

A parte III focalizava a produção discente nos âmbitos oral e escrito. Para ambas as produções, incentivei os alunos a expressarem suas interpretações sobre o texto a partir de composições menos tradicionais, que possivelmente dialogassem com alguma forma de arte. Na produção oral, por exemplo, uma aluna optou por gravar um vídeo cantando uma canção original inspirada pelo conto; quanto à escrita, era possível produzir desenhos, pinturas, poemas ou quaisquer outras representações artísticas impulsionadas pelo conto. Os alunos também poderiam optar por desenvolver textos em gêneros mais tradicionais, se desejassem.

O quadro a seguir apresenta as orientações referentes à produção escrita, que são o objeto de interesse neste artigo.

Quadro 2. Instruções para a produção escrita decorrente do projeto

In this part of our project, we will focus on creating something with everything we learned throughout these weeks. Choose only one option.

OPTION A - creating a review

As a reader, your opinion of the short story is very valid! So, share it with everyone in a review about the story. Consider the following topics:

- brief description of what the story is about (plot);

- your overall opinion;

- positive aspects;

- negative aspects;

- would you recommend it to other readers?

OPTION B - creating a work of art

Literature is art. So why not express your opinions through another work of art? Here are some suggestions of what you can create to express your opinions of the story:

- a poem (or another short story),

- a painting;

- a drawing;

- a musical interpretation,

- any other kind of art that represents the story

Fonte: elaboração própria

Das 22 produções discentes, 13 foram elaboradas a partir de um viés artístico: houve 5 poemas, 4 desenhos/ pinturas, 2 contos que davam continuação ao texto original, 1 colagem digital e 1 composição a partir de memes. Diante das limitações e do escopo do artigo, selecionei, para análise, 3 trabalhos ${ }^{6}$ que me impactaram emocionalmente e afetivamente. Sem intenção de hierarquizar as produções, ressalto o olhar artístico que evidenciam a natureza contextual, discursiva e translíngue da linguagem nesses trabalhos, conforme discuto a seguir.

6. Todos os alunos deram seu consentimento para a análise e publicação de suas produções. 


\section{AS PRODUÇÕES DISCENTES}

Os trabalhos focalizados aqui apontam para o reconhecimento, da parte dos alunos, de que a língua é apenas um dos recursos semióticos - e talvez o mais superestimado (BLOOMMAERT, 2019) - envolvido no processo de construção de sentidos. Esse reconhecimento, é importante destacar, não é enunciado por eles de modo teórico, já que muitos são estudantes de graduação das várias áreas de conhecimento.

Suas identidades, visões de mundo e suas relações com o texto atravessam uma visão contextualizada e posicionada de língua, que se materializam em suas produções, como revela a imagem a seguir.

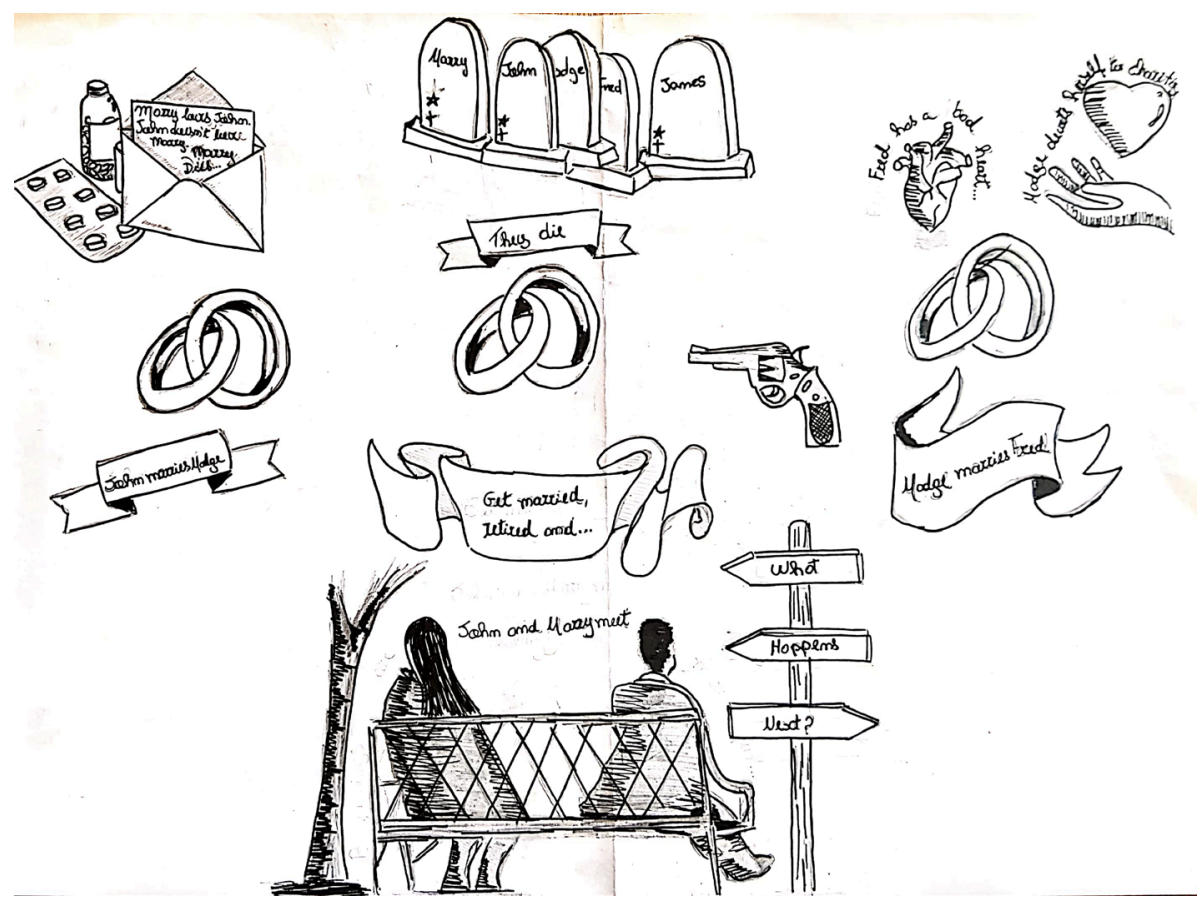

Imagem 2. Renarrando a narrativa, por Nayara ${ }^{7}$

Fonte: elaboração da aluna Nayara

A composição de Nayara é sustentada por diferentes bases que, além de aludirem ao texto literário trabalhado em aula, também remetem aos seus conhecimentos e repertórios, dando origem a uma produção autoral que ecoa os discursos, as temáticas e a estrutura formal da narrativa. Assim como na apresentação das atividades do projeto, os desenhos criados pela estudante podem ser lidos de maneira não-linear, em alusão à própria estrutura fragmentada do texto. Não obstante, os símbolos não-verbais (as lápides representando a morte de todos os personagens, a repetição das alianças ilustrando três momentos distintos do texto, o coração metaforizando a doença de um personagem, as placas sinalizando um caminho cíclico das relações), acompanhados da linguagem verbal parecem compor diferentes cenas que, por um lado, refletem a interpretação da estudante frente ao conto, mas por outro, convocam o leitor a trafegar por entre essas cenas a fim de construir a sua própria leitura.

Estabelece-se, assim, na imagem, uma dinamicidade construída a partir da interrelação entre diferentes sistemas semióticos. É por meio do posicionamento da aluna frente a esses sistemas que múltiplas relações dialógicas são postas em circulação, potencializando movimentos fluidos em muitas direções: da estudante ao conto; de suas compreensões às possíveis interpretações do leitor; da autora do texto original à autora dessa imagem.

Dessa forma, a produção pode ser vista como um retrato de prática transformada pautada em "um novo uso de materiais antigos, uma rearticulação e recombinação de recursos postos nos designs disponíveis" (COPE; KALANTZIS, 2000, p. 22).

$\mathrm{Na}$ mesma direção, junto a Cope e Kalantzis (2013), entendo que ao se apropriar de recursos disponíveis (available designs), como o próprio texto literário, e ressignificá-los a partir de suas visões de mundo, Nayara atua em um processo ativo (designing) de construção de sentidos a partir desses recursos para criar um trabalho que é, ao mesmo tempo, produto e material de produção para releituras futuras. Como discutem Cope e Kalantzis (2013,

7. Todos os nomes são fictícios. À época da disciplina, Nayara era graduanda em enfermagem na Unicamp. 
p. 117), designing é um processo em que se busca "interagir com recursos disponíveis (como a escrita, a oralidade, a criação de imagens) para representar o mundo ou representar as representações de outras pessoas sobre o mundo", justamente o que ilustra a composição de Nayara.

Avalio, ainda, que a atividade proposta foi uma oportunidade de vivenciar o letramento crítico a partir de um ângulo de afetividade, especialmente porque sem a restrição da produção a um gênero específico, o que possivelmente levaria a trabalhos mais "engessados", os alunos puderam recorrer aos seus conhecimentos e habilidades (como o desenho, no caso de Nayara) para fazer emergir suas identidades e subjetividades. Nesse sentido, concordo com Takaki (2019, p. 214) que "fazer a diferença pelos letramentos críticos é propiciar meios para o aluno ver o que não vê, sentir o que não sente, escrever, produzir trabalhos com recursos tecnológicos e multimodais (se possível) mas que tenham significado na vida diária deles."

A próxima produção também é um retrato da conjugação dos repertórios dos alunos aos sentidos do conto.

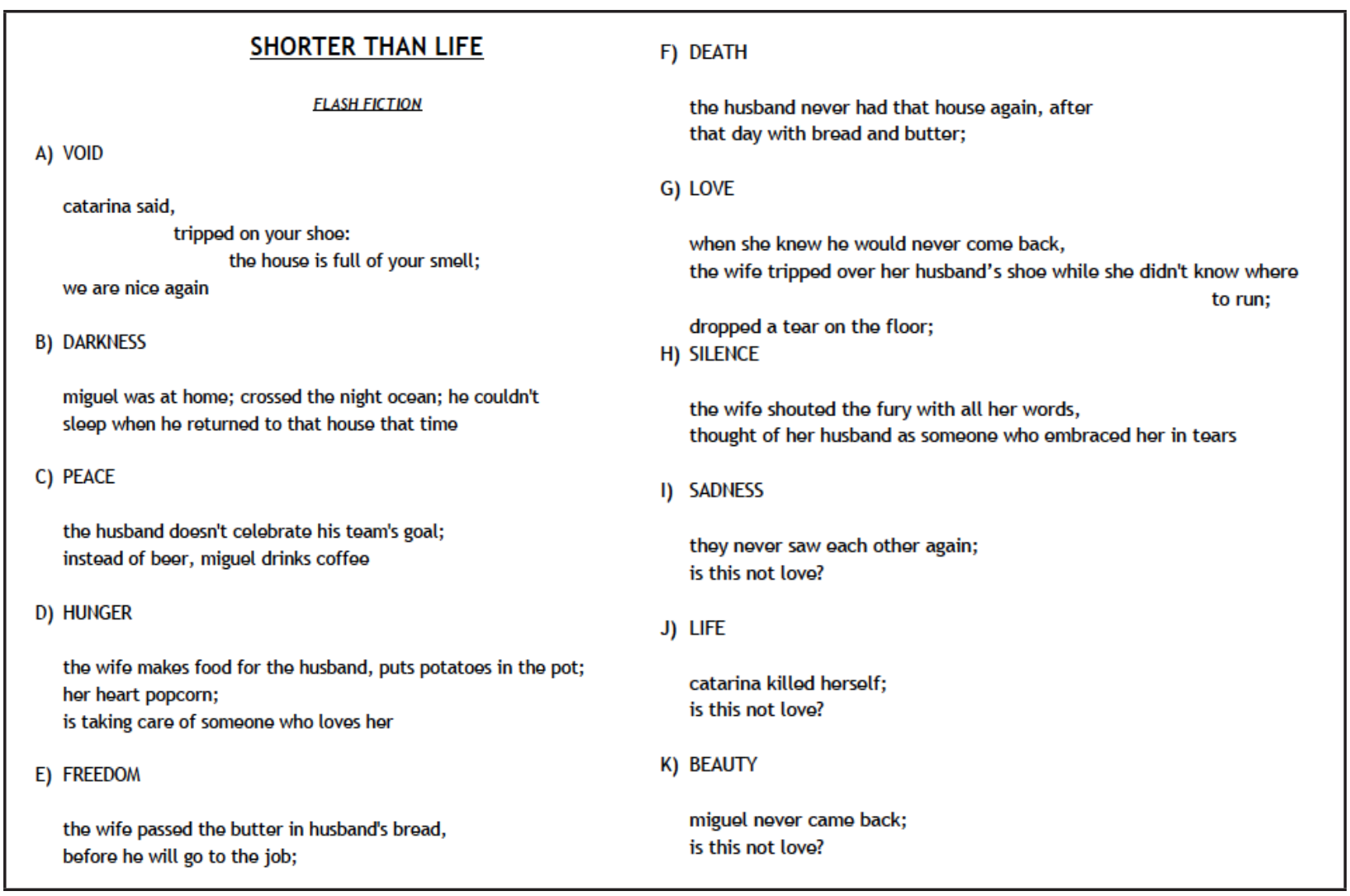

Imagem 3. Flash fiction, por Eduardo 8

Fonte: elaboração do aluno Eduardo

Em um primeiro olhar, o aspecto que mais chama a atenção na produção de Eduardo é a relação muito próxima com a estrutura do conto de Atwood, que também é dividido em pequenas partes (de A a F). O estabelecimento da intertextualidade, nesse caso, parece inicialmente servir ao propósito de posicionar o leitor no mesmo espaço formal e temático para, em seguida, ampliar as delimitações do texto original em uma prática não somente revisitada, mas transformada. O estudante exerce sua agência ao introduzir novos personagens e revestir de poesia a sua versão de uma narrativa que, sem se limitar à relação intertextual, emerge como um produto novo, marcado pela originalidade e por sua potência poética.

Além de transitar entre a prosa e a poesia, Eduardo também joga com um gênero até então não explorado nas aulas, as flash fictions, atestando, mais uma vez, o valor das propostas que validem os conhecimentos prévios dos estudantes. Nesse trilhar de diferentes gêneros a que Eduardo nos convida a experimentar, nos deparamos com um

8. Eduardo era aluno de ciência da computação no momento da disciplina. Seu texto está reproduzido em forma de imagem para evitar desconfigurar a métrica e a formatação originalmente pensadas pelo aluno. 
texto marcado pela fluidez e pela autoria de seu criador, que mesmo sem enunciar explicitamente, parece operar com uma perspectiva de língua como força discursiva irrestrita a barreiras rígidas.

A produção é especialmente significativa se considerarmos que foi desenvolvida por um aluno em estágios iniciais de aprendizagem de língua inglesa. Assim sendo, mais do que destacarmos as inadequações gramaticais do texto, assumo, junto a Jordão (2019, p. 75), um olhar ampliado para língua e prática social ao reconhecer que nossos alunos são seres inteligentes, e podemos pressupor, então, que os usos diferentes da língua por eles produzidos sejam
ressignificações, usos criativos dos recursos linguísticos, ao invés de nos precipitarmos caracterizando como "erros" ou "desvios" da
norma os usos que fogem de nossas expectativas.

Isso não significa, todavia, que reflexões sobre o uso da norma culta e do funcionamento formal da língua não sejam relevantes ou não devam ser abordados na educação linguística. Trata-se, a meu ver, de olharmos nossos alunos e suas muitas capacidades para além de uma visão conservadora de língua, o que contribui, inclusive, para a construção de uma relação respeitosa e menos autoritária entre docentes e discentes.

Ao construir seu próprio texto literário em meio aos movimentos entre gêneros, Eduardo nos mostra que, como afirma Cosson (2020, p. 47), "a literatura é uma prática e um discurso, cujo funcionamento deve ser compreendido criticamente pelo aluno". Não há dúvidas, em minha análise, de que a compreensão crítica, nesse caso, se efetivou e deu vazão a uma nova forma artística.

Como nos ensina García (2020a, p. XIX), a construção de sentidos através da linguagem em uma perspectiva translíngue "acontece no cruzamento de disciplinas acadêmicas incluindo as artes, a poesia, a performance (...) junto àquilo que entendemos ser o linguístico, incluindo os letramentos". Nesse sentido, o entrecruzamento de conhecimentos e a força poética na produção de Eduardo cavam espaço para o sentimento, por vezes ausente em nossos contextos pedagógicos. Assim, mais do que atestar as capacidades linguísticas ou seu nível de proficiência, o texto "Shorter Than Life" corrobora o que afirma Nóvoa (2021, s/p): "não se pode saber sem sentir (...); na prática do sentir há também conhecimento".

A próxima produção segue ilustrando e ratificando a relevância desse debate. Nesse caso, o trabalho é composto majoritariamente por imagens e, portanto, é mais longo do que o recorte apresentado aqui. Algumas imagens foram omitidas e o layout foi alterado (aqui, as imagens aparecem em duas colunas) para não comprometer a extensão deste artigo; os textos em inglês foram mantidos conforme originalmente apresentados.

A

John and Mary happy with a life stimulanting and challenging and a very perfect family.

Expectation:

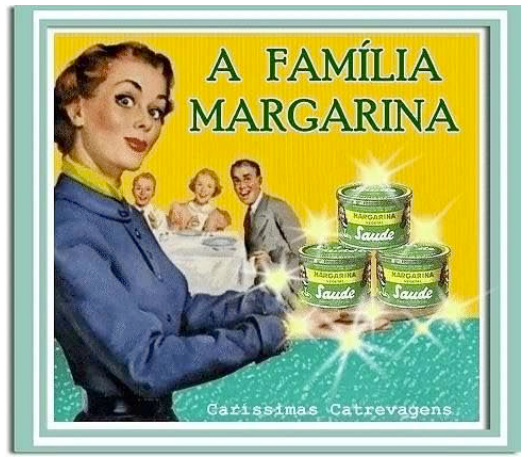

Reality:

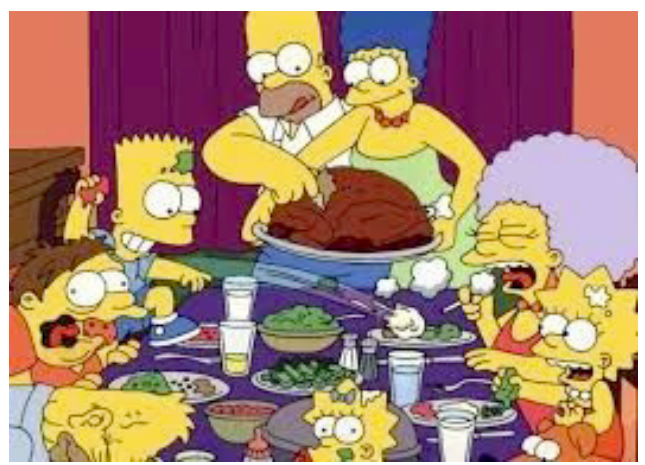


B

Mary to want to be with John even though he doesn't love her:

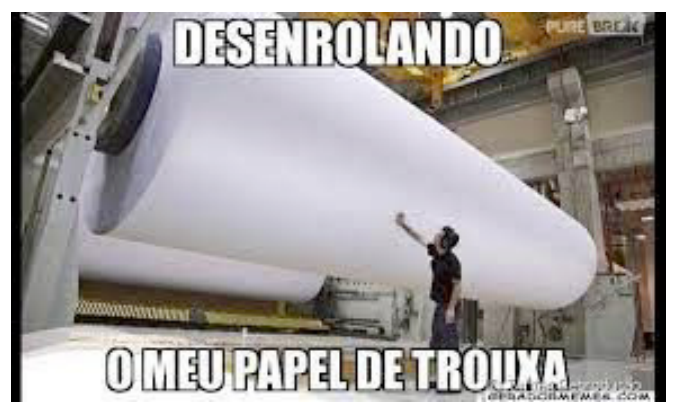

C

Mary with John thinks about James

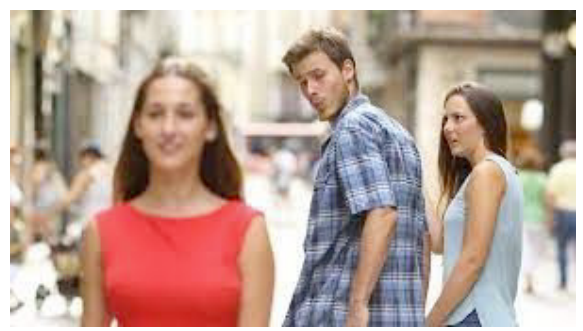

D

Madge and Fred really happy

D. Thelma *0

O início de um sonho // DEU

TUDO CERTO

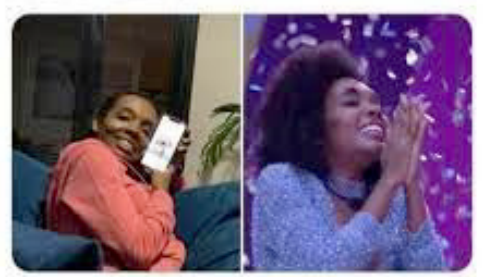

Mary's friends try to warn her:

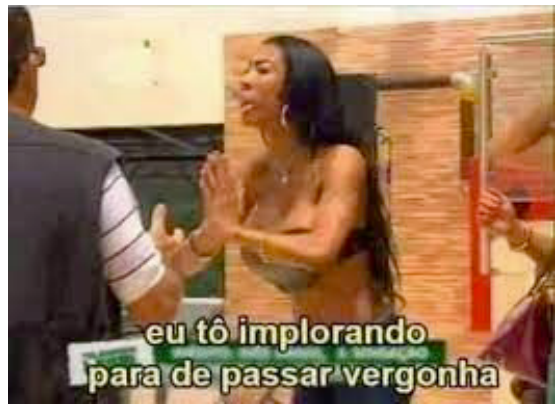

John see Mary with James:

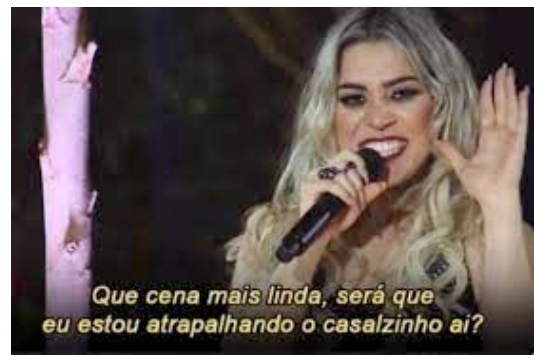

They save themselves from the gigant tidal:

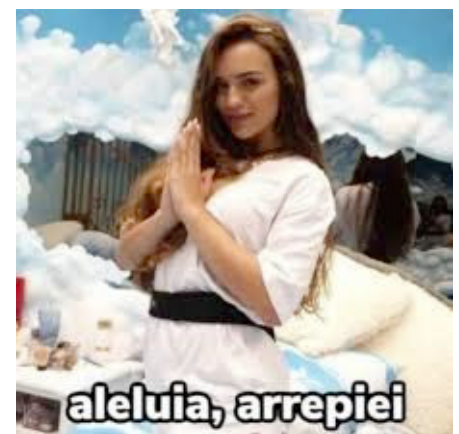

E

Fred dies, Mary

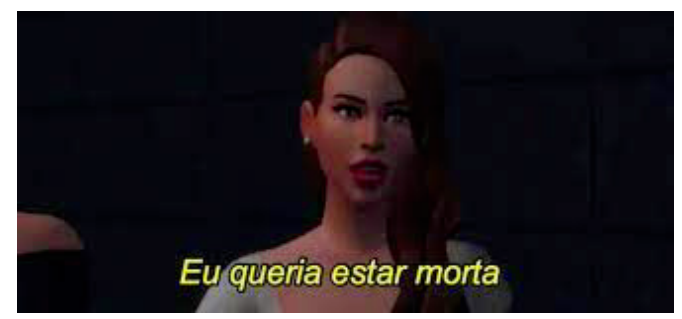


$\mathrm{F}$
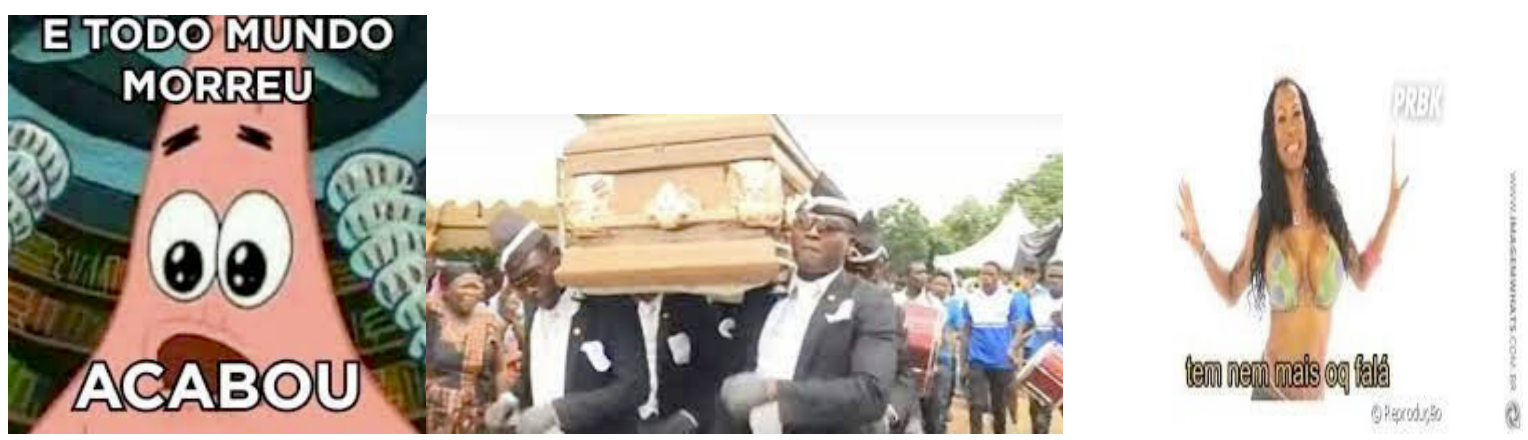

Imagem 4. Ressemiotizando o texto literário, por Paula

Fonte: elaboração da aluna Paula

Como se nota, o trabalho de Paula extravasa barreiras de gênero e de linguagem ao constituir-se em uma composição marcada pela profusão de sentidos, sinalizando que a aluna opera com noções complexas sobre a natureza situada e multimodal da linguagem e que, provavelmente, está ciente de seus efeitos para a prática social. Assim, ao movimentar-se entre diferentes sistemas semióticos, Paula se apropria de sentidos evidenciados por uma linguagem específica - os memes - para ressignificar o conto original e, então, transportar o leitor para um espaço de humor, diversidade e afetividade. Além disso, ao acionar diferentes recursos de seu repertório, Paula se engaja em um processo ativo de translinguajar, "transcendendo as línguas nomeadas e indo além delas" (KLEYN, GARCÍA, 2019, p. 71).

Essa produção reforça, como discute Jordão (2019), que o trabalho com textos e com letramento crítico está intimamente vinculado à afetividade porque ao mergulharmos em um texto não nos relacionamos com a materialidade das palavras, mas com as emoções e os sentimentos que elas despertam em nós. Entendo, assim, que a composição de Paula dialoga diretamente com o potencial do afeto pois, como discute Rocha (2020, p. 121), "nossos sentidos e afetos são culturalmente constituídos e, portanto, sempre ideologicamente marcados". Desse modo, Paula se pauta em uma concepção de cultura como discurso e como prática para trazer à baila, com os memes, sentidos e afetos culturalmente e socialmente localizados.

Nesse horizonte, a produção de Paula é representativa do que Rojo (2013, p. 20) entende como uma "multissemiose" e "múltiplos modos de significar" que emergem com os novos letramentos. É, também, um produto reprojetado (redesgined), que, como tal, é retrato das subjetividades e da agência humana fundadas em bases históricas, sociais e culturais específicas que, certamente, impactam na construção de sentidos, como nos ensinam Cope e Kalantzis (2000).

É importante destacar que em uma sociedade que transborda rigidez e que demoniza aquilo que erroneamente entende ser uma pedagogia crítica, a composição de Paula desafia essas noções ao ser justamente a materialização da criatividade crítica (GARCÍA, 2019) da aluna. Assim, essa prática transformada e reprojetada poderia também ser compreendida como um "texto híbrido de diferentes letramentos", nos termos de Rojo (2013, p. 18), marcado por um "processo de escolha pessoal e política, e de hibridização de produções de diferentes 'coleções".

Em sua teorização sobre letramento literário, Cosson (2020) afirma compreender a literatura como um polissistema devido à sua capacidade de abrigar, em si própria, tanto o canônico como as produções culturais de massa, o que inclui, por vezes, as vozes hegemônicas, mas também o discurso desestabilizador da opressão. Essa consideração é significativa, sobretudo para a educação linguística, pois a renarrativa de Paula marcada pela linguagem dos memes ressitua, de maneira formal e crítica, a atualidade dos temas centrais do conto, e assim estabelece novos sentidos e inicia novos diálogos com leitores que transitam pelos mesmos repertórios.

$\mathrm{Na}$ mesma direção, a literatura se revela um sistema também polissêmico, como ilustram as produções aqui discutidas. Para Eduardo, o conto inspirou uma nova produção literária marcada pela poesia e amparada em um tom mais realista; já Paula, por sua vez, reinterpretou o conto à luz do humor. Esses dois casos, assim como a produção de Nayara, evidenciam que os alunos rompem com a rigidez da língua e dos gêneros para estampar suas identidades e afetividades em textos transformados e, certamente, transformadores. A esse respeito, alinho-me a Cosson (2020, 
p. 16): "é no exercício da leitura e da escrita dos textos literários que se desvela a arbitrariedade das regras impostas pelos discursos padronizados da sociedade letrada e se constrói um modo próprio de se fazer dono da linguagem que, sendo minha, é também de todos."

Todas essas produções corroboram a certeza de que a criatividade de nossos alunos, sempre criticamente e politicamente marcada, é uma força indispensável para a educação linguística e sem a qual os multiletramentos e os letramentos críticos não se efetivam. A abertura da possibilidade de construírem sentidos a partir de trabalhos menos engessados, mesmo em um espaço acadêmico, também levou à criação de um espaço "seguro" em que os alunos pudessem compartilhar suas visões de mundo - inspiradas pelo conto - a partir dos conhecimentos e habilidades que fazem sentido para eles. Não há dúvidas, portanto, de que nessas configurações, as produções discentes reverberam a capacidade da literatura em se comunicar, de modo mais direto e urgente, com nossos sentimentos e emoções, constituindo-se em um retrato de afetividades resgatadas em tempos de tantas perdas.

Em que medida, então, as propostas aqui discutidas se relacionam com os discursos perigosos da normalização de cenários nada normais, conforme discutido anteriormente? Amparo-me em Freire (2014) para compreender essas produções como movimentos em busca do inédito-viável, da construção de possibilidades mais humanas e justas de enfrentamento das situações-limites a partir da educação. A literatura, neste caso, trouxe afetividade para um contexto marcado pelo distanciamento, e assim, representou uma força epistemológica e discursiva capaz de viabilizar a construção de saberes menos rígidos em tempos que pediam justamente isso: olhares mais sensíveis para o mundo. Nesse sentido, os letramentos literários e críticos tornaram-se um caminho acolhedor para que nós, docentes e estudantes, pudéssemos esperançar.

\section{CONSIDERAÇÕES FINAIS}

Recupero discussões iniciais deste artigo ao reiterar que, tão difícil quanto narrar os tempos horrorosos em que vivemos, é encontrar e construir sentidos em nossas salas de aula - agora virtuais - em meio a tantas perdas. $\mathrm{O}$ que fazemos de nossas práticas e contextos educacionais quando a urgência da vida transborda e, assim, não pode ser colocada em segundo plano?

Resistimos na educação porque esse também é um espaço de existência/resistência em que nossas vulnerabilidades e afetividades podem se materializar como força política em defesa da vida social e coletiva. A educação que se quer efetivamente crítica não se desvincula do potencial da sensibilidade e dos sentimentos na interrogação das desigualdades. É nesse caminho - sem diminuir quaisquer formas de luta - que vejo ser possível e desejável o desenho de uma educação libertária (hooks, 2017) e menos desumanizadora, porque calcada na força da esperança teimosa de seus professores (FREIRE, 2014).

As produções discentes aqui discutidas sinalizam, pelo menos para mim, que a educação linguística também pode ser um espaço de visibilização da esperança na medida em que abrimos mão de convicções epistemológicas para, juntamente aos nossos alunos, buscarmos (sobre)viver em meio ao caos. Os alunos cujas composições analisei neste texto parecem, a todo momento, ainda que sem teorizar dessa forma, desafiar as premissas modernistas e monolíticas que tantas vezes fomentamos, em nossas práticas, ao reduzirmos o ensino de línguas a propósitos estritamente instrumentais. Como reflete García (2020a), enquanto insistirmos em uma educação linguística preocupada apenas com a língua como sistema fechado, deixaremos de explorar o potencial de outras práticas pedagógicas e, inevitavelmente, invalidaremos tudo (que é tanto) o que está à margem.

Recupero, então, questionamentos que fiz no início deste texto: que sentidos criamos em nossas práticas pedagógicas em tempos, por vezes, incompreensíveis? As propostas aqui discutidas apontam, a meu ver, para a necessidade de resgate do que é primordial, indispensável e efetivamente "normal": o afeto, o sentimento e a esperança. Seja na produção de Paula, em sua arquitetura multissemiótica que hibridiza gêneros e ecoa humor e leveza apesar de tantos pesares; seja na produção de Eduardo, na qual a intertextualidade propõe inúmeros diálogos e nos traz vida ao recontar a narrativa original pela ótica da poesia; seja na interpretação de Nayara, cujos desenhos e símbolos dispostos de forma não-linear refletem o potencial da criatividade dos alunos quando lhes são dadas oportunidades para produções menos conservadoras; seja nas demais produções não discutidas neste texto: os sentidos que criamos na educação linguística libertária e transgressora (hooks, 2017) são aqueles que nos permitem resgatar a vida, a humanização, o afeto e a resistência, que (tanto) nos faltam em tempos sombrios como esses. 
Neste trabalho e nas propostas aqui discutidas, a literatura e suas muitas dimensões de metamorfose em discurso, parafraseando Cosson (2020), mostrou-se uma voz que dialoga, desde sempre, muito diretamente com as minhas identidades. Porém, meu objetivo, aqui, não foi apresentar uma receita a ser seguida, tampouco apontar um único caminho para cavar espaços visando os letramentos críticos e afetivos. Meu desejo, como educador, é que as diversas formas de arte, em toda sua amplitude, possam sempre nos inspirar a esperançar freireanamente, e, assim, revestir nossas práticas pedagógicas de mais afeto, sentimento e intimidade, que neste momento, parece ser o que realmente importa.

\section{REFERÊNCIAS}

ADICHIE, C. N. (2009). A private experience. Disponível em https://www.theguardian.com/books/2008/dec/28/chimamandangozi-adichie-short-story Acesso em: 15 abr 2020.

ATWOOD, M. (1983). Happy Endings. In: A Murder in the Dark: Short Fictions and Prose Poems. Toronto: Coach House Books. Disponível em https://learning.hccs.edu/faculty/selena.anderson/engl2328/readings/happy-endings-by-margaretatwood/view Acesso em: 13 jul. 2021.

BLOOMMAERT, J; GARCÍA, O; KRESS, Gi LARSEN-FREEMAN, D. (2019). Communicating Beyond Diversity: A Bricolage of Ideas. In: SHERRIS, A; ADAMI, E (Eds.) Making Signs, Translanguaging, Etbnograpbies - Exploring Urban, Rural an Educational Spaces. Bristol (UK): Multilingual Matters, p. 9-35.

CANDIDO, A. (2004). O Direito à Literatura. In: CANDIDO, A. Vários Escritos. 4ed. São Paulo/Rio de Janeiro: Duas Cidades, p. $169-191,1995$.

CERVENAK, S. J; CESPEDES, K. L; SOUZA, C; STRAUB, A. (2002). Imagining differently: the politics of listening in a feminist classroom. In: ANZALDÚA, Gi KEATING, A. (Eds.). This bridge we call home: radical visions for transformation. 1st ed. Routledge, p. 341-356 https://doi.org/10.4324/9780203952962 Acesso em: 22 jun. 2021.

COPE, B; KALANTZIS, M. (2000). Design, Culture, Transformation. In: COPE, B. KALANTZIS, M. (eds). Multiliteracies: literacy learning and the design of social futures. London, Routledge.

COPE, B; KALANTZIS, M. (2013). "Multiliteracies": New Literacies, New Learning. In: HAWKINGS, M. R. (ed.). Framing languages and literacies: socially situated views and perspectives. New York: Routledge, p. 105-135.

COSSON, R. (2000) Letramento literário: teoria e prática. 2a. ed. São Paulo: Editora Contexto, 2006.

DUBOC, A. P. Mi FERRAZ, D. de M. (2018). Reading ourselves: placing critical literacies in contemporary language education. Revista Brasileira de Linguística Aplicada, v. 18, n. 2, p. 227-254. Disponível em: http://dx.doi.org/10.1590/19846398201812277 Acesso em: 22 de jun. 2021.

FERRAZ, D de $M_{i}$ KAWACHI-FURLAN, C. J. (2019). As imagens nas aulas de inglês: Por um letramento visual ético e responsável. In: FERRAZ; D. De Mi KAWACHI-FURLAN, C. J. (Orgs.). Bate-papo com educadores linguísticos: letramentos, formação docente e criticidade. 1ed. São Paulo: Pimenta Cultural, 2019, p. 245-263.

FREIRE, P. (2014). Pedagogia da esperança: um reencontro com a pedagogia do oprimido. Rio de Janeiro/São Paulo: Paz e Terra, 1992.

GARCIA, A.; LUKE, A, SEGLEM, R. (2018). Looking as the Next 20 Years of Multiliteracies: a Discussion with Allan Luke. Theory Into Practice, v. 57, Taylor \& Francis Online. p. 72-78. Disponível em https://doi.org/10.1080/00405841.2017.1390 330 Acesso em: 12 de jul. 2021.

GARCÍA, O. (2020a) Foreword: co-labor and re-performances. In: MOORE, E; BRADLEY, J; SIMPSON, J. (Eds.) Translanguaging as transformation: the collaborative construction of new linguistic realities. Multilingual Matters, p. xvii $-\mathrm{xxii}$. 
GARCÍA, O. (2020b). The education of latinx bilingual children in times of isolation: unlearning and relearning. MinneTESOL Journal, v. 36. Disponível em http://minnetesoljournal.org/journal-archive/mtj-2020-1/the-education-of-latinx-bilingualchildren-in-times-of-isolation-unlearning-and-relearning/ Acesso em 12 de jul, 2021.

HAN, B. (2017). Sociedade do Cansaço. Petrópolis: Vozes.

hooks, b. (2017). Ensinando a transgredir: a educação como prática da liberdade. 2a. ed. Tradução de Marcelo Brandão Cipolla. São Paulo: Editora WMF Martins Fontes, 1994.

JORDÃO, C. M. (2019) O lugar da emoção na criticidade do letramento. In: FERRAZ; D. de M; KAWACHI-FURLAN, C. J. (orgs.) Bate-papo com educadores linguísticos: letramentos, formação docente e criticidade. São Paulo: Pimenta Cultural, p. $71-78$.

KAWACHI, G. J. (2015) Ensino de inglês para a interculturalidade: investigando práticas e representações discentes no ProFIS/ Unicamp. Tese de Doutorado em Linguística Aplicada. Instituto de Estudos da Linguagem, Unicamp, Campinas.

KLEYN, T; GARCÍA, O. (2019). Translanguaging as an Act of Transformation: Restructuring Teaching and Learning For Emergent Bilingual Students. In: OLIVEIRA, L. C de. The Handbook of TESOL in K-12, p. 69-92. Disponível em https://doi. org/10.1002/9781119421702.ch6 Acesso em: 13 jul 2021.

LAZZARATO, M. (2019) O neoliberalismo em chave estratégica. São Paulo: N-1 Edições.

LIBERALI, F. C. (2020). Construir o inédito viável em meio à crise do coronavírus - Lições que aprendemos, vivemos e propomos. In: LiBERALI, F. C; FUGA, V. P; DIEGUES, U. C. C; CARVALHO, M. P. (orgs.). Brincando em tempos de pandemia: brincando com um mundo possível. Campinas: Pontes, p. 13-21.

LUKE, A. Defining critical literacy. (2014). In: PANDYA, J. Z; AVILA, J. (Eds.). Moving critical literacies forward: a new look at praxis across contexts. New York: Routledge, p.19-31.

MATTOS, A. M. A. (2014). Construindo cidadania nas aulas de inglês: uma proposta para o letramento crítico. In: TAKAKI, N. H.; MACIEL, R. F. (Orgs.). Letramentos em terra de Paulo Freire. Campinas: Pontes Editores, p.171 -194.

MBEMBE, A. (2016). Necropolítica. Ares \& Ensaios, n. 32. Disponível em: https://revistas.ufrj.br/index.php/ae/article/view/8993. Acesso em: 12 jul. 2021

MENEZES DE SOUZA, L. M. T. (2011). Para uma redefinição de Letramento Crítico: conflito e produção de significação. In: MACIEL, R. F; ARAUJO, V. A. (Orgs.). Formação de professores de línguas: ampliando perspectivas. Jundiaí: Paco editorial, p. $128-140$.

MENEZES DE SOUZA, L. M. T.; MONTE MOR, W. (2021) Afterwords - Hope and Education in Dystopic Times: Thinking about the Present as if from the Future. Revista Brasileira de Linguística Aplicada, v. 21, n. 2, p. 657-670. Disponível em http:// dx.doi.org/10.1590/1984-6398202118373. Acesso em 12 de jul. 2021.

MONTE MOR, W. (2013). Crítica e Letramentos Críticos: reflexões preliminares. In: ROCHA, C. H.; MACIEL, R. F. (Orgs.). Lingua estrangeira e formação cidadã: por entre discursos e práticas. Campinas: Pontes Editores, p. 31-59.

MONTE MÓR, W. (2018). Letramentos Críticos e Expansão de Perspectivas: Diálogo sobre Práticas. In: JORDÃO, C. M; MARTINEZ, J. Z; MONTE MÓR, W. (Orgs.). Letramentos em Prática na Formação Inicial de Professores de Inglês. Campinas: Pontes Editores, p. 315-335.

MORRISON, T. (2015). Sweetness. The New Yorker. Disponível em https://www.newyorker.com/magazine/2015/02/09/ sweetness-2 Acesso em 13 jul 2021.

MILLS, K. Critical Literacies. (2016). In: MILLS, K (Ed.) Literacy theories for the digital age: social, critical, multimodal, spatial, material, and sensory lenses. Multilingual Matters, p. 41-64. 
NOVOA, A; ALVIM, Y. (2020). Nothing is New, But Everything Has Changed: A Viewpoint on the Future. Prospects, p. $35-41$. Disponível em https://doi.org/10.1007/s11125-020-09487-w. Acesso em: 12 jul. 2021.

NOVOA, A. (2021) Aprendizagem precisa considerar o sentir. Revista Educação. Disponível em https://revistaeducacao.com. br/2021/06/25/antonio-novoa-aprendizagem-sentir. Acesso em: 12 jul. 2021.

ROCHA, C. H. (2020). Escute com seu corpo: o potencial subversivo do afeto em tempos sombrios, Revista X, v.15, n.4, p. $115-125$. Disponível em: https://revistas.ufpr.br/revistax/article/view/76202. Acesso em 12 jul. 2021.

ROJO, R. H. R (2009). Letramentos Múltiplos: escola e inclusão social. São Paulo: Parábola.

ROJO, R. H. R. (2013). Gêneros discursivos do círculo de Bakhtin e multiletramentos. In: ROJO, R.H.R. (org.), Escol@ conect@d@: os multiletramentos e as TICs.1a. ed. São Paulo: Parábola, p.13-36.

SELWYN, N. (2017) Um panorama dos estudos críticos em educação e tecnologias digitais. In: ROCHA, C. H, EL KADRI, M. S; WINDLE, J. (Orgs.) Diálogos em tecnologia educacional: educação linguística, mobilidade e práticas translíngues. Campinas: Pontes Editores, p. 15-40.

TAKAKI, N. H. (2019). É o que somos, sendo: o papel da (auto)crítica nos letramentos. In: FERRAZ, D. de M.; KAWACHIFURLAN, C. J. (Orgs.). Bate-papo com educadores linguísticos: letramentos, formação docente e criticidade. São Paulo: Pimenta Cultural, p. 199-216.

TAKAKI, N. H. (2021). Critical Literacy with (Freire) and for the Other (Levinas): Ethics/Social Justice as Enigmatic Becoming. Revista Brasileira de Linguística Aplicada, v. 21, n. 2, 2021, p. 627-655. Disponível em: http://dx.doi.org/10.1590/19846398202117392. Acesso em: 22 de jun. 2021.

Recebido: 14/7/2021

Aceito: 14/10/2021

Publicado: 26/10/2021 